LPPM UNIHAZ $\quad \begin{array}{lll}\text { ABDIHAZ: Jurnal Ilmiah Pengabdian pada Masyarakat } \\ \text { https://journals.unihaz.ac.id/index.php/abdihaz }\end{array}$

\title{
Moringa oleifera L. sebagai Solusi Sosioekonomi dan Kesehatan Masyarakat dalam Menghadapi Pandemi Covid-19 di Bengkulu
}

\section{Moringa oleifera L. for Socioeconomic and Public Health Solutions in Facing the Covid-19 Pandemic in Bengkulu}

\author{
Risnita Tri $\operatorname{Utami}^{1 *}$, Marlinah $^{2}$ \\ ${ }^{1}$ Program Studi Akuakultur, Universitas Prof. Dr. Hazairin, SH, Jl. Jend. Sudirman No. 185 Bengkulu, Indonesia \\ ${ }^{2}$ Fakultas Hukum, Universitas Prof. Dr. Hazairin, SH, J1. Jend. A. Yani No. 1 Bengkulu, Indonesia
}

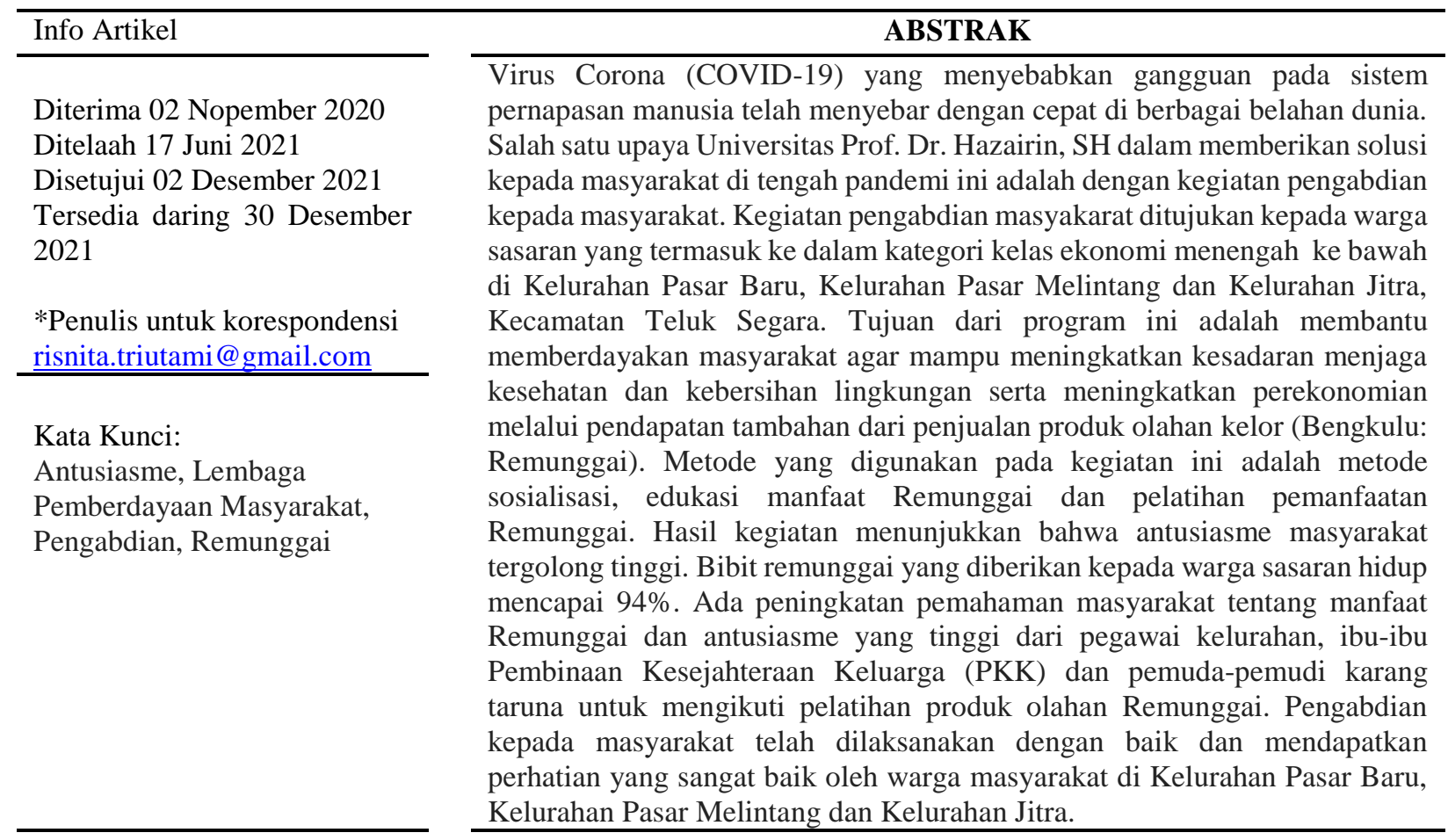

Keywords:

Enthusiasm, Community Empowerment Institutions, Moringa, Service

\section{ABSTRACT}

The Corona virus (COVID-19) which causes disorders of the human respiratory system has spread rapidly in various parts of the world. One of Universitas Prof. Dr. Hazairin, SH's efforts in providing solutions to the community during this pandemic was through community service activities. The target of the community service activities were residents who fall into the middle to lower economic class category in Pasar Baru, Pasar Melintang, and Jitra sub-districts, Teluk Segara district. The purpose of this program was to help empower the community to increase awareness of maintaining health and environmental hygiene as well as improving the economy through additional income from sales of moringa processed products. The methods used in this activity were socialization, education on the benefits of moringa, and training for the use of moringa. The results of the activity showed that the enthusiasm of the community was high. It could be seen from the seedlings of moringa that were given to life target residents reaching 94\%. Furthermore, the 
understanding of the benefits of moringa increased during this program. The high enthusiasm was also seen from the village employees, PKK women, and youth groups to attend training on moringa processed products. Community service has been carried out well and received very good attention from community members in Pasar Baru, Pasar Melintang, and Jitra sub-districts.

ISSN 2685-0354 (Media Online). Diterbitkan oleh Universitas Prof. Dr. Hazairin, SH. Ini merupakan jurnal bebas akses di bawah lisensi Creative Commons Atribution 4.0 International.

\section{PENDAHULUAN}

Virus Corona jenis baru yaitu Severe Acute Respiratory Syndrome Coronavirus 2 (SARSCOV2) yang menyebabkan penyakit Coronavirus Disease-2019 (COVID-19) merupakan virus yang menyerang sistem pernapasan manusia. Pandemi Covid-19 pertama kali ditemukan di Kota Wuhan, Provinsi Hubei, Tiongkok pada bulan Desember 2019. Data World Health Organization (WHO) menunjukkan kasus covid-19 telah menyebar di 216 Negara dan telah menyebabkan gangguan sosioekonomi secara global, termasuk Indonesia (https://www.covid19.go.id/). Jumlah pekerja Indonesia yang telah dirumahkan dan terkena pemutusan hubungan kerja (PHK) akibat terdampak covid-19 mencapai 2.084.593 pekerja dari 116.370 perusahaan (Karunia, 2020). Obat dan vaksin untuk covid-19 hingga saat ini belum ditemukan. Upaya pencegahan yang direkomendasikan oleh WHO yaitu dengan mencuci tangan secara teratur, menutup mulut dan hidung ketika batuk dan bersin, serta hindari kontak dengan orang yang menunjukkan gejala penyakit pernapasan.

Covid-19 telah menyebar dengan cepat di berbagai belahan dunia, oleh sebab itu perlunya edukasi di masyarakat untuk menjaga kesehatan dan kebersihan lingkungan agar terhindar dari virus ini. Program pengabdian kepada masyarakat Universitas Prof. Dr. Hazairin SH, Bengkulu (Unihaz) merupakan wahana penyelesaian suatu permasalahan berbasis kearifan dan potensi lokal serta kerjasama antara masyarakat dan pemerintah setempat.

Remunggai (Moringa oleifera) termasuk ke dalam Ordo Brassicales dengan Famili Moringaceae memiliki ciri-ciri berupa semak atau pohon dengan tinggi mencapai $11 \mathrm{~m}$. Remunggai dikenal juga sebagai Tree For Life/ The Miracle Tree. Julukan ini diberikan karena Remunggai mengandung 46 anti oksidan yang dapat melindungi tubuh dari radikal bebas, 18 asam amino, 36 senyawa anti inflamasi, serta 90 nutrisi alami seperti vitamin dan mineral. Kandungan vitamin dan mineral yang terkandung dalam Remunggai, diantaranya: vitamin A, vitamin C, vitamin B, Kalsium, Kalium, Besi dan Protein dalam jumlah yang tinggi dan mudah dicerna oleh tubuh manusia. Semua bagian dari Remunggai mulai dari akar, daun, batang, getah, bunga hingga bijinya dapat dimanfaatkan sebagai bahan pangan, kesehatan, lingkungan dan bahan kecantikan/ kosmetik (Anwar, Ashraf, \& Gilani, 2007; Thurber \& Fahey, 2009; Krisnadi, 2015; Isnan \& Nurhaedah, 2017). . Daun remunggai memiliki berbagai nutrisi yang bermanfaat (Fuglie, 2001). Kandungan yang paling tinggi pada daun remunggai yaitu protein, vitamin A dan zat besi yang dapat memenuhi kebutuhan gizi manusia (Madukwa, Ugwuoke, \& Ezeugwu, 2013).

Daun remunggai banyak diformulasikan ke dalam produk pangan untuk menambah nilai gizinya seperti biskuit (Kholis \& Hadi, 2010), soy meatball (Evivie, Ebabhamiegebho, Imaren, \& Igene, 2015), yoghurt (Diantoro, Rohman, Budiarti, \& Palupi, 2015) dan produk permen jeli (Rahmawati \& Adi, 2016). Dengan diolahnya daun kelor menjadi makanan kudapan yang disukai oleh semua kalangan, maka akan meningkatkan pemanfaatan daun kelor di masyarakat sehingga kandungan gizi serta manfaat lainnya yang terdapat pada daun kelor dapat diserap oleh tubuh. 
Remunggai juga sukses dalam memerangi malnutrisi pada anak-anak dan meningkatkan imunitas/sistem kekebalan tubuh manusia serta dapat mengatasi masalah gizi buruk anak dan ibu hamil (Price, 2000). Manfaat lainnya dari Remunggai antara lain: secara ekologi dapat memperbaiki lahan yang kritis dan menjernihkan air alami, sumber makanan, khasiat penyembuhan berbagai penyakit, super nutrisi untuk lansia, serta sumber energi terbarukan (Krisnadi, 2015).

Kasus covid-19 di Bengkulu terkonfirmasi positif per tanggal 12 Juni 2020 telah mencapai 95 jiwa yang telah menyebabkan 4 jiwa meninggal dunia. Kegiatan pengabdian masyarakat oleh Unihaz di situasi pandemi ini harus memberikan dampak yang positif yaitu berupa penyelesaian masalah yang dihadapai oleh masyarakat di Kelurahan Pasar Baru, Kelurahan Pasar Melintang dan Kelurahan Jitra, Kecamatan Teluk Segara. Adapun tujuan dari kegiatan pengabdian masyarakat ini adalah dapat memberdayakan masyarakat dalam penanaman pohon Remunggai, mengedukasi masyarakat tentang manfaat Remunggai sebagai solusi meningkatkan imun/ daya tahan tubuh dalam menghadapai pandemi covid-19 serta pelatihan pengolahan Remunggai sebagai sumber pangan/kudapan untuk meningkatkan pendapatan tambahan dari penjualan pangan fungsional/ kudapan tersebut.

\section{METODE}

Kegiatan pengabdian ini dilaksanakan pada bulan Juli-Agustus 2020 di Kota Bengkulu yaitu Kelurahan Pasar Baru, Pasar Melintang dan Jitra. Program ini dilaksanakan dengan metode sosialisasi, edukasi manfaat Remunggai dan pelatihan pengolahan produk dari Remunggai.

\section{Metode Sosialisasi Penyerahan Bibit Remunggai}

Pada tahap sosialisasi ini dilakukan pendekatan kepada Lurah di kelurahan setempat bahwa akan dipilih beberapa warga untuk mendapatkan bibit Remunggai. Bibit Remunggai ini kemudian akan dibagikan ke beberapa warga terpilih sehingga dapat dimanfaatkan secara langsung oleh warga tersebut.

\section{Metode Edukasi Manfaat Remunggai dan Gerakan Cuci Tangan}

Metode edukasi berupa informasi dan manfaat Remunggai kepada warga sasaran. Edukasi ini berupa membagikan brosur yang berisi seluk beluk informasi Remunggai, fakta nutrisi serta pemanfaatannya sebagai produk makanan kudapan. Makanan kudapan ini berfungsi meningkatkan imunitas/ daya tahan tubuh sebagai upaya pencegahan Covid-19 di tengah masyarakat Kota Bengkulu. Selain brosur atau panduan tentang manfaat Remunggai juga dibagikan brosur cuci tangan dengan sabun dan didemokan di depan masyarakat "Gerakan Cuci Tangan (Gecit)" sebagai upaya pencegahan Covid-19 di tengah masyarakat Kota Bengukulu.

\section{Metode Pelatihan Produk Berbasis Remunggai}

Organisasi non pemerintah (NGO), Educational Concerns for Hunger Organization (ECHO) merekomendasikan penambahan daun Remunggai kering dalam bentuk serbuk untuk ditambahkan ke dalam makanan dapat digunakan sebagai nutrisi tambahan pada anak ( Zakaria, Thamrin, Lestari, \& Hartono, 2013; Srikanth, Mangala, \& Subrahmanyam, 2014). Remunggai dapat dimanfaatkan sebagai suatu pangan fungsional atau kudapan di berbagai kalangan masyarakat. Dengan memformulasikan bubuk daun Remunggai ke dalam berbagai kudapan akan menambah nilai gizi yang terkandung didalamnya. Adapun contoh kudapan yang dapat dibuat dari 
Remunggai diantara lain: teh tubruk/ teh celup, puding, siomay, bakso dan lain sebagainya. Selain itu, serbuk Remunggai juga dapat digunakan sebagai masker wajah dimana Remunggai ini mempunyai antioksidan yang bagus untuk kulit wajah. Hasil produk dari Remunggai ini akan didemokan kepada warga sasaran untuk dilihat dan dirasakan secara langsung oleh mereka.

\section{HASIL DAN PEMBAHASAN}

\section{Sosialisasi Penyerahan Bibit Remunggai}

Kegiatan pengabdian Unihaz tahun 2020 dilakukan di Kecamatan Teluk Segara terutama di Kelurahan Pasar Baru, Kelurahan Pasar Melintang dan Kelurahan Jitra. Warga sasaran pada kegiatan ini berjumlah 280 orang yang tersebar di tiga Kelurahan di Kecamatan Teluk Segara (Gambar 1). Warga sasaran penerima pohon Remunggai di Kecamatan Teluk Segara berasal dari beberapa elemen masyarakat atau jenis pekerjaan. Warga sasaran di Kelurahan Pasar Baru, paling banyak merupakan warga dengan pekerjaan swasta (pedagang, penjahit, tukang, bengkel, buruh dan wiraswasta) mencapai 55\%, 21\% PegawaI Negeri Sipil (PNS), 16\% Ibu Rumah Tangga (IRT) dan 8\% lainnya (pegawai BUMN, pensiunan, honorer, mahasiswa, dan pastur). Warga sasaran di Kelurahan Jitra tersebar di lima Rukun Tetangga (RT), dimana warga berasal dari berbagai jenis pekerjaan. Jenis pekerjaan paling banyak di kelurahan ini adalah swasta (karyawan swasta, pedagang, buruh harian lepas, nelayan, dan supir ) sebesar 60\%, Ibu Rumah Tangga 20\%, Pensiunan 8\%, Pegawai Negeri Sipil 7\% dan lainnya 5\% (honorer, lansia, Pembantu Rumah Tangga, dan tidak bekerja). Dilihat dari persentase jenis pekerjaan di Kecamatan Teluk Segara rata-rata adalah Ibu Rumah Tangga yang mencapai 20\%, dan pekerjaan swasta mencapai 55-60\% dimana rata-rata jenis pekerjaannya adalah pedagang, buruh lepas dan nelayan. Apabila dilihat dari data ini, lebih dari 50\% warga di Kelurahan Pasar Baru, Kelurahan Pasar Melintang dan Kelurahan Jitra masuk ke dalam kategori kelas ekonomi menengah ke bawah.

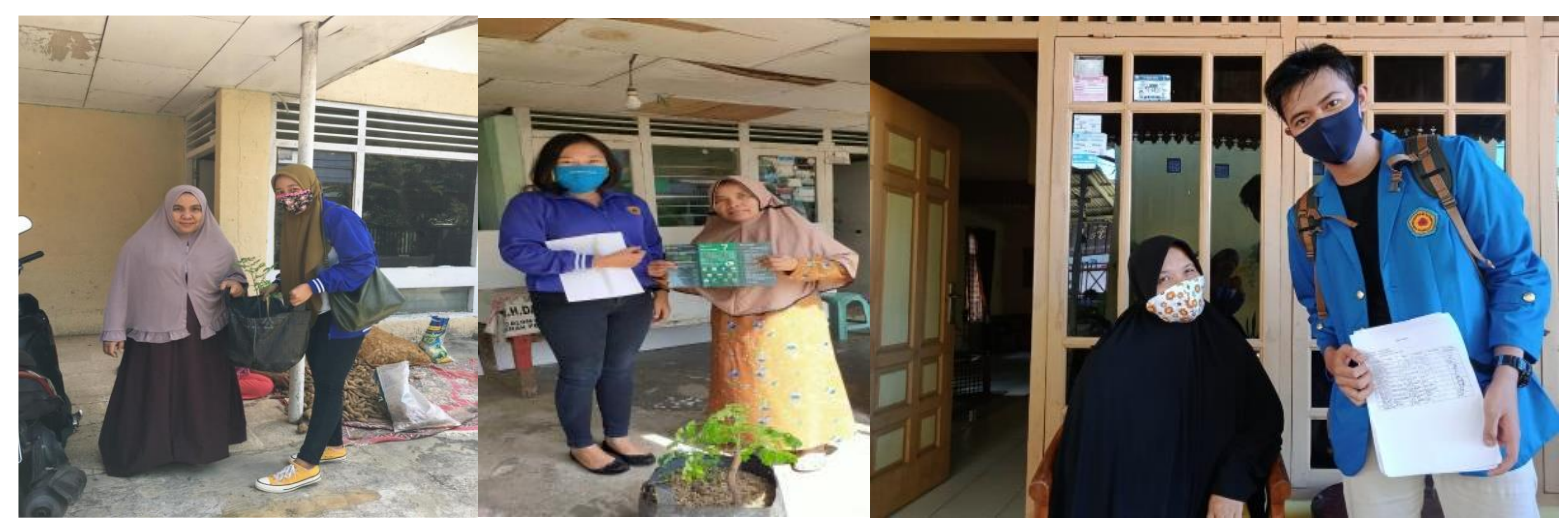

Gambar 1 Warga Sasaran dari Kelurahan Jitra, Pasar Melintang dan Pasar Baru

Tabel 1 Jumlah Bibit Remunggai yang Hidup/ Mati

\begin{tabular}{clcc}
\hline No. & Kelurahan & Bibit yang Hidup & Bibit yang Mati \\
\hline 1. & Pasar Baru & 82 & 8 \\
2. & Pasar Melintang & 82 & 8 \\
3. $\quad$ Jitra & 98 & 2 \\
\hline Jumlah & 262 & 18 \\
\hline
\end{tabular}


Kegiatan Penyerahan bibit kepada masyarakat di Kelurahan Pasar Baru, Kelurahan Pasar Melintang dan Kelurahan Jitra dilaksanakan pada tanggal 1-7 Juli 2020 dan mendapat respon baik dari masyarakat penerima bibit tersebut. Setelah menerima bibit Remunggai, masyarakat pun ikut serta dalam membantu dengan cara merawat bibit Remunggai tersebut selama 40 hari kegiatan sampai seterusnya. Proses pemantauan atau monitoring dilakukan minimal 2 kali seminggu selama 40 hari kegiatan pengabdian. Perkembangan bibit Remunggai pun sangat baik pada setiap minggunya (Tabel 1). Hasil monitoring tanaman Remunggai di Kelurahan Jitra, Kelurahan Pasar Baru dan Kelurahan Pasar Melintang tumbuh subur dan baik serta antusiasme warga sangat baik. Warga Kelurahan Jitra, Kelurahan Pasar Baru dan Kelurahan Pasar Melintang sangat mendukung program pengabdian ini. Hal ini terlihat dari jumlah bibit yang hidup dan dipelihara oleh warga mencapai $94 \%$.

\section{Edukasi Manfaat Remunggai dan Gerakan Cuci Tangan}

Sosialisasi tentang Remunggai dilaksanakan di Kantor Kelurahan Jitra pada tanggal 5 Juli 2020 pukul 14:00 WIB- selesai. Sosialisasi diikuti oleh pegawai kelurahan, RT, RW, Lembaga Pemberdayaan Masyarakat (LPM), tokoh masyarakat dan warga perwakilan masing-masing RT. Sosialisasi tentang Remunggai juga dilaksanakan di kantor Kelurahan Pasar Melintang pada tanggal 27 Juli 2020 pukul 08:00 WIB- selesai. Sosialisasi diikuti oleh pegawai kelurahan pasar melintang warga perwakilan masing-masing RT. Sosialisasi yang dilakukan adalah penjelasan manfaat dan khasiat Remunggai dalam meningkatkan imunitas untuk mencegah covid-19. Selain edukasi manfaat Remunggai dilakukan juga pembagian produk yaitu puding dari Remunggai sebagai bentuk dari inovasi baru yang akan diberikan kepada warga di Kelurahan Jitra, Pasar Baru dan Pasar Melintang (Gambar 2). Edukasi Gerakan Cuci Tangan dilakukan dengan cara membagi brosur cuci tangan yang baik kepada warga sasaran di Kelurahan Jitra, Pasar Baru dan Pasar Melintang. Brosur cuci tangan dibagikan agar warga mengetahui cara cuci tangan dengan baik dan selalu menjaga kebersihan.

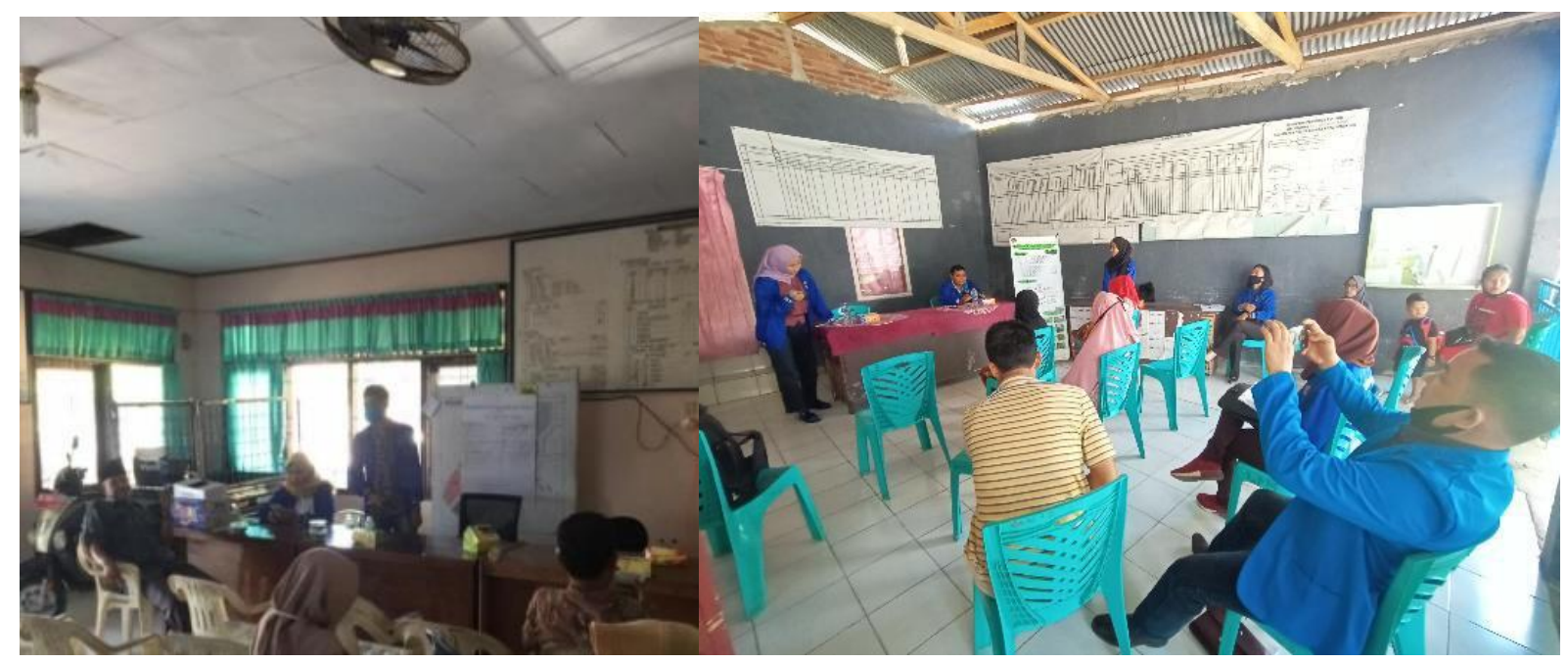

Gambar 2 Edukasi tentang remunggai, manfaat dan cara pengolahan produknya

Pada kegiatan pengabdian diberikan beberapa pertanyaan yang disusun dalam angket yang telah diberikan kepada warga untuk mengetahui pengetahuan dan pemahaman warga sasaran tentang Remunggai. Pemberian angket ini dilakukan sebanya 2 kali yaitu Angket 1 pada saat penyerahan bibit dan Angket 2 pada saat monitoring bibit terakhir. 
Tabel 2 Angket 1 Pengetahuan dan Pemahaman Warga Tentang Remunggai

\begin{tabular}{|c|c|c|c|c|c|c|}
\hline \multirow{2}{*}{ No. } & \multirow{2}{*}{ Pertanyaan } & \multicolumn{5}{|c|}{ Jumlah Jawaban } \\
\hline & & A & B & $\mathrm{C}$ & $\mathrm{D}$ & $\mathrm{E}$ \\
\hline 1 & Tentang pohon Remunggai & 28 & 145 & 41 & 65 & 1 \\
\hline 2 & Sejak kapan Bapak/Ibu mengenal pohon Remunggai & 10 & 146 & 57 & 54 & 13 \\
\hline 3 & Daun Remunggai sangat bermanfaat bagi kesehatan & 115 & 140 & 11 & 10 & 4 \\
\hline 4 & Pohon Remunggai mengandung mistik & 12 & 124 & 55 & 72 & 17 \\
\hline 5 & $\begin{array}{l}\text { Menanam pohon Remunggai dapat menghilangkan } \\
\text { kekuatan mistik }\end{array}$ & 11 & 102 & 50 & 88 & 29 \\
\hline 6 & $\begin{array}{l}\text { Menanam/memelihara dan mengelola pohon } \\
\text { Remunggai akan membantu dapur keluarga }\end{array}$ & 48 & 203 & 29 & 0 & 0 \\
\hline 7 & $\begin{array}{l}\text { Kegiatan penanaman pohon Remunggai oleh } \\
\text { mahasiswa UNIHAZ pada setiap rumah warga }\end{array}$ & 173 & 94 & 13 & 0 & 0 \\
\hline 8. & Saya bersedia menanam pohon Remunggai, karena & 225 & 42 & 2 & 11 & 0 \\
\hline 9 & $\begin{array}{l}\text { Setiap warga di Bengkulu wajib menanam pohon } \\
\text { Remunggai }\end{array}$ & 87 & 146 & 36 & 11 & 0 \\
\hline 10 & Remunggai dijadikan ikon / ciri khas Bengkulu & 47 & 72 & 105 & 39 & 17 \\
\hline
\end{tabular}

Keterangan: A: Sangat Setuju; B: Setuju; C: Kurang Setuju; D: Tidak Setuju; E: Sangat Tidak Setuju

Tabel 3 Angket 2 Pengetahuan dan Pemahaman Warga Tentang Remunggai

\begin{tabular}{|c|c|c|c|c|c|c|}
\hline \multirow{2}{*}{ No. } & \multirow{2}{*}{ Pertanyaan } & \multicolumn{5}{|c|}{ Jumlah Jawaban } \\
\hline & & A & B & $\mathrm{C}$ & $\mathrm{D}$ & $\mathrm{E}$ \\
\hline 1 & Tentang pohon Remunggai & 51 & 165 & 16 & 47 & 1 \\
\hline 2 & Sejak kapan Bapak/Ibu mengenal pohon Remunggai & 33 & 135 & 68 & 40 & 3 \\
\hline 3 & Daun Remunggai sangat bermanfaat bagi kesehatan & 93 & 162 & 23 & 2 & 0 \\
\hline 4 & Pohon Remunggai mengandung mistik & 18 & 112 & 68 & 82 & 0 \\
\hline 5 & $\begin{array}{l}\text { Menanam pohon Remunggai dapat menghilangkan } \\
\text { kekuatan mistik }\end{array}$ & 7 & 106 & 58 & 109 & 0 \\
\hline 6 & $\begin{array}{l}\text { Menanam/memelihara dan mengelola pohon Remunggai } \\
\text { akan membantu dapur keluarga }\end{array}$ & 51 & 199 & 25 & 4 & 2 \\
\hline 7 & $\begin{array}{l}\text { Kegiatan penanaman pohon Remunggai oleh mahasiswa } \\
\text { Unihaz pada setiap rumah warga }\end{array}$ & 187 & 87 & 4 & 2 & 0 \\
\hline 8 & Saya bersedia menanam pohon Remunggai, karena & 243 & 9 & 9 & 17 & 2 \\
\hline 9 & $\begin{array}{l}\text { Setiap warga di Bengkulu wajib menanam pohon } \\
\text { Remunggai }\end{array}$ & 112 & 138 & 20 & 8 & 2 \\
\hline 10 & Remunggai dijadikan ikon / ciri khas Bengkulu & 75 & 58 & 91 & 33 & 23 \\
\hline
\end{tabular}

Keterangan: A: Sangat Setuju; B: Setuju; C: Kurang Setuju; D: Tidak Setuju; E: Sangat Tidak Setuju

Pemberian angket 1 menunjukkan bahwa sekitar 27\% warga sangat mengetahui dan memahami tentang Remunggai beserta manfaatnya, 43\% warga yang sudah mengetahui dan memahami tentang Remunggai beserta manfaatnya dan hanya $1 \%$ yang sangat tidak tahu dan memahami tentang Remunggai beserta manfaatnya. Oleh karena itu, tujuan dilaksanakannya pengabdian ini adalah untuk mengedukasi pemahaman tentang Remunggai,manfaat beserta cara pengoahan produk dari Remunggai kepada masyarakat di Kelurahan Pasar Baru, Kelurahan Pasar Melintang dan Kelurahan Jitra. 
Pemberian angket kedua menunjukkan peningkatan sebesar $4 \%$ dari pemberian angket yang pertama yaitu sekitar $31 \%$ warga sangat mengetahui dan memahami tentang Remunggai beserta manfaatnya, $42 \%$ warga yang sudah mengetahui dan memahami tentang Remunggai beserta manfaatnya dan hanya $1 \%$ yang sangat tidak tahu dan memahami tentang Remunggai beserta manfaatnya. Hal ini menunjukkan bahwa lebih dari 50\% warga sudah memahami tentang Remunggai beserta manfaatnya dari sejak zaman dahulu.

\section{Pemberian Olahan dan Pelatihan Pengolahan Produk Remunggai}

Dalam pelaksanaan kegiatan pengabdian, yaitu mengolah Remunggai menjadi puding dan bakso. Pelaksanaan Pembuatan olahan puding dan bakso dilaksanakan pada tanggal 25 Juli 2020. Selanjutnya pada Tanggal 26 Juli 2020, kami memberikan olahan produk kepada warga sasaran di Kelurahan Pasar Melintang (Gambar 3).

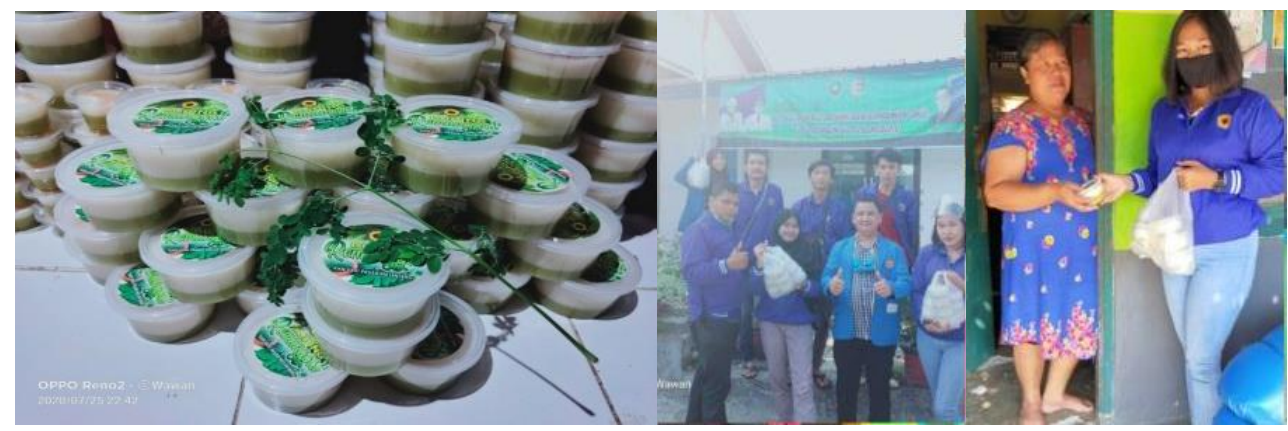

Gambar 3 Pemberian produk olahan dari Remunggai kepada warga di Kelurahan Pasar Melintang

Demo masak dilaksanakan pada hari Sabtu, tanggal 8 Agustus yang dilaksanakan di kantor Kelurahan Jitra (Gambar 4). Sebelum melaksanakan demo masak produk olahan siomay Remunggai di kelurahan dilakukan penjelasan mengenai manfaat dan khasiat Remunggai. Demo masak diikuti oleh pegawai kelurahan, ibu-ibu PKK dan pemuda-pemudi karang taruna. Demo masak bertujuan untuk memberitahu manfaat dari Remunggai serta mengajarkan bagaimana membuat olahan produk dari Remunggai sehingga masyartakat dapat mengetahui proses pembuatan olahan-olahan dari Remunggai.
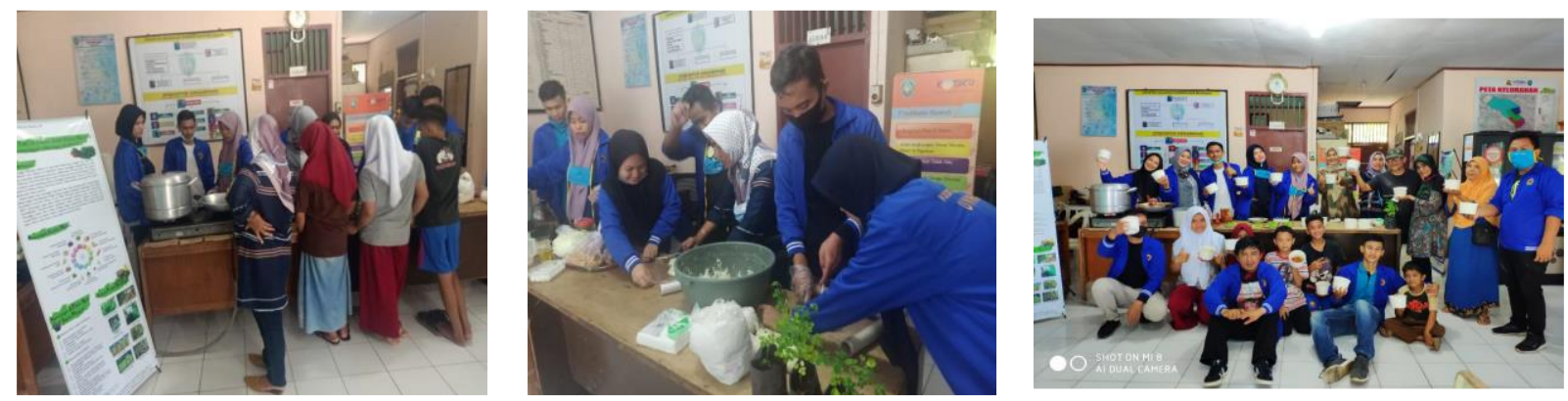

Gambar 4 Demo masak produk olahan dari Remunggai di Kantor Kelurahan Jitra

\section{KESIMPULAN}

Dengan adanya pengabdian masyarakat ini telah membantu merubah pola pikir masyarakat sasaran yang mendapatkan bibit Remunggai terkait manfaat Remunggai dan upaya pencegahan covid-19 di masyarakat secara umum. Kegiatan pengabdian masyarakat ini juga meningkatan nilai tambah produk dari sisi Iptek dengan penerapan teknologi pengolahan produk dari Remunggai 
yang belum pernah dilakukan sebelumnya. Teknik ini merupakan alternatif pemecahan masalah sosioekonomi dan kesehatan masyarakat, sehingga dapat meningkatkan pendapatan masyarakat dan meningkatkan imunitas di tengah pandemi covid-19 ini.

Penyuluhan dan penguatan kelompok telah dilaksanakan dengan baik dan mendapatkan perhatian yang sangat baik dengan kehadiran anggota kelompok mitra yang diundang. Penerapan teknologi pengolahan produk dari Remunggai berjalan dengan baik, hampir seluruh peserta memiliki antusias yang baik.

\section{UCAPAN TERIMA KASIH}

Penulis mengucapkan terima kasih kepada Lembaga Penelitian dan Pengabdian Kepada Masyarakat Universitas Prof. Dr. Hazairin, SH Bengkulu yang telah memberikan dana pengabdian. Lurah Kelurahan Pasar Baru, Kelurahan Pasar Melintang, Kelurahan Jitra, Camat Kecamatan Teluk Segara serta rekan-rekan yang telah membantu jalannya pengabdian ini.

\section{DAFTAR PUSTAKA}

Anwar, F., Latif, S., Ashraf, M., \& Gilani, A. H. (2007). Moringa oleifera: A food plant with multiple medicinal uses. Phytother. Res, 21, 17-25. https://doi.org/10.1002/ptr.2023.

Satuan Tugas Penanganan COVID-19. (2020) Infografis covid-19 12 Juni 2020. Diakses pada https://covid19.go.id/p/berita/infografis-covid-19-12-juni-2020 .

Diantoro, A., Rohman, M., Budiarti, R., \& Palupi, H. T. (2015). Pengaruh penambahan ekstrak daun kelor (Moringa oleiera L.) terhadap kualitas yoghurt. Jurnal Teknologi Pangan, 6(2), no. 1: 59-66.

Evivie, S., Ebabhamiegebho, P., Imaren, J., \& Igene, J. (2015). Evaluating the organoleptic properties of soy meatballs (beef) with varying level of moringa oleifera leaves powder. Journal Application Science Environment Management (JASEM), 649-656.

Fuglie, L. (2001). Combating malnutrition with moringa. Development Potential for Moringa Products, 1(1), 1-4.

Isnan, W., \& Nurhaedah, M. (2017). Ragam manfaat kelor (Moringa oleifera Lamk.) bagi masyarakat. Info Teknis EBONI, 14(10):63-75.

Karunia, A. M. (2020). Dampak Covid-19, Menaker: Lebih dari 2 Juta Pekerja Di-PHK dan Dirumahkan. Diakses pada https://money.kompas.com/read/2020/04/23/174607026/ dampak-covid-19-menaker-lebih-dari-2-juta-pekerja-di-phk-dan-dirumahkan

Kholis, N., \& Hadi, F. (2010). Pengujian bioassay biskuit balita yang disuplementasi konsentrat protein daun kelor (Moringa Oleifera) pada model tikus malnutrisi. Jurnal Teknologi Pertanian, 11(3), 144-151.

Krisnadi, A. D. (2015). Kelor Super Nutrisi. kelorina.com

Madukwe, E., Ugwuoke, A. \& Ezeugwu, J. (2013). Effectiveness of dry moringa oleifera leave powder in treatment of anemia. Academic Journals, 5(5), 226-228.

Price, M.L. (2007). The Moringa Tree. Durrance Road, North Forth Myers, USA: ECHO.

Rahmawati, P. S., \& Adi, A. C. (2016). Daya terima dan zat gizi permen jeli dengan penambahan bubuk daun kelor (Moringa oleifera). Media Gizi Indonesia, 11(1), 86-93.

Srikanth, V. S., Mangala, S., \& Subrahmanyam, G. (2014). Improvement of protein energy 
malnutrition by nutritional intervention with Moringa oleifera among Anganwadi children in rural area in Bangalore, India. Int J Sci Stud, 2(1), 32-35.

Thurber, M. D. \& Fahey, J. W., (2009). Adoption of Moringa oleifera to combat undernutrition viewed through the lens of the "diffussion of innovations" theory. Ecol Food Nutr, 8(3), $212-225$.

Zakaria, Thamrin, A., Lestari, R. S., \& Hartono, R. (2013). Pemanfaatan tepung kelor (Moringa oleifera) dalam formulasi pembuatan makanan tambahan untuk balita gizi kurang. Media Gizi Pangan, 15(1), 1-6. 